\title{
The Baltic and Scandinavia: Introduction
}

\author{
Geoff Bailey and Hauke Jöns
}

\section{Abstract}

This section deals with some of the largest concentrations of underwater sites in Europe. Because of the complex history of isostatic rebound and periodic damming back of the Baltic Sea associated with the retreat of the Scandinavian ice sheet, these chapters also present a wide range of preservation conditions and palaeoenvironmental changes, ranging from shorelines that have been lifted clear of sea-level rise in Norway and parts of Sweden but without organic preservation, to sinking shorelines on the Baltic coastlines of Denmark and Germany with little overburden of marine sediments and spectacular organic preservation, to open-coast conditions along the North Sea shorelines of Denmark and Germany where sites are mostly buried under thick marine deposits. Many sites in Denmark and Germany have benefited from systematic excavation, demonstrating that the majority of finds and features have been recovered from

G. Bailey $(\bowtie)$

Department of Archaeology, University of York, York, UK

College of Humanities, Arts and Social Sciences, Flinders University, Adelaide, SA, Australia

e-mail: geoff.bailey@york.ac.uk

H. Jöns

Lower Saxony Institute for Historical Coastal Research, Wilhelmshaven, Germany

e-mail: joens@nihk.de marine refuse areas in shallow water along the shoreline and that the adjacent settlement areas originally located on dry land have been largely eroded away or badly disturbed by subsequent sea-level rise. The abundance of finds and excellent preservation in many cases reflect the high marine productivity of the Littorina Sea and the concentration of settlements on the shoreline with a heavy emphasis on marine resources, the presence of coastal topography conducive to trapping of fish and sea mammals, the deposition of cultural material directly into shallow water with finegrained sediments where items were quickly buried and protected from bacterial attack or marine erosion and the occurrence of settlements in relatively shallow water easily accessible to diver investigation. There is considerable scope for new investigations and new discoveries, not only in Denmark and Germany but also in Norway, where study of the numerous Stone Age sites on uplifted shorelines has overshadowed investigation of the many regions with inundated coastlines, in Sweden, where the Early Mesolithic period, almost non-existent on the submerged shorelines of Denmark and Germany, is represented by an extensive and relatively shallow submerged landscape with excellent preservation conditions, and further east in the Baltic on the coastlines of Poland, Lithuania and Latvia, with offshore conditions similar to those of 
Germany and Denmark and the likelihood that numerous submerged sites of high scientific value await discovery.

\section{Keywords}

Early Mesolithic $\cdot$ Early Neolithic $\cdot$ Ertebølle - Marine refuse area Isostatic rebound .

Excavation

\subsection{Introduction}

The four regions covered by the chapters in this section together have the largest number of underwater sites in Europe, accounting for fully $1968(75 \%)$ of the finds recorded in the SPLASHCOS Viewer and a correspondingly large number of in situ culture layers. The majority of these sites are in Denmark (1699), but there are significant numbers in the other regions in this section: 142 sites in Germany, 83 in Norway and 44 in Sweden. Many sites, of course, are single finds or unstratified material that may have been subjected to post-depositional disturbance, but the number of sites with in situ cultural layers, and especially ones that have been tested or more fully excavated, is unusually high. Three chapters-Denmark, Sweden and Germanydeal with a closely related group of regions in the south-western Baltic, which share many similarities in terms of geological and hydrological history, archaeological sequences and preservation conditions. Norway, properly speaking, falls within the North Sea and Atlantic group of chapters and is briefly referred to later in the introduction to Part II (Peeters et al., Chap. 7, this volume), but its geological history of isostatic rebound and its archaeological sequence have more in common with the Baltic group, and we discuss the results from Norway here. Denmark and Germany also have coastlines bordering the North Sea, with coastal conditions and submerged landscapes that have much in common with other coastlines around the southern rim of the North Sea. They have received rather less attention and yielded far fewer underwater finds than their
Baltic counterparts, largely it seems because of the greater difficulties of accessing the buried Stone Age land surface.

All the regions discussed in this section have been dominated by geological processes associated with the expansion and contraction of the Scandinavian ice sheet. These processes include major reshaping of the physical landscape by ice action during the Last Glacial Period and vertical movements of the Earth's crust associated with glacio-hydro-isostatic changes in mass loading. These processes in their turn have interacted with eustatic changes in ocean volume to create a complex history of changing coastlines, with very significant implications for the differential preservation and visibility of coastal settlements and underwater finds.

All four regions have other features in common in addition to the impact of isostatic movements. These include the following:

- A relatively short archaeological sequence compared to the other regions of Europe, beginning with earliest human entry into new territory made available by the retreat of the Scandinavian ice sheet, and therefore only very few finds, whether on land or under water, earlier than the Late Glacial (from, at earliest, c. 16,000 years onwards).

- A kaleidoscope of rapidly and quite dramatically changing Late Pleistocene and Early Holocene climates, coastlines, vegetation conditions and available terrestrial and marine food resources.

- Excellent conditions of accessibility and preservation of underwater material with some of the best examples available of organic artefacts made from wood and plant fibres and unique insights into the nature of the conditions in which underwater archaeological deposits are preserved.

- Heavy emphasis on coastal settlement and exploitation of marine resources from the earliest period of human colonisation, resulting from a combination of productive marine environments and hinterlands of relatively limited extent or productivity. 
In this introduction, we summarise the Late Glacial and Early Postglacial geological history of the region and highlight the principal archaeological findings from each country with reference to the geological processes affecting the visibility of palaeoshorelines, exploitation of marine resources, conditions of underwater preservation, the reasons for the large number of finds and the impact of industrial collaboration.

\subsection{Geological, Palaeogeographical and Climatic History}

The geological process that dominates all the areas examined here is glacio-isostatic adjustment (GIA) - the isostatic rebound of the land following the melting of the Scandinavian ice sheet. The rate of uplift or subsidence varied in different regions and interacted with eustatic sealevel rise to create complex patterns of palaeogeographic change including submergence or elevation of shorelines and periodic isolation of the Baltic Basin to form a freshwater lake isolated from the world oceans (see Jöns et al. 2011; Jöns and Harff 2014; Rosentau et al. 2017, for general overviews, and the chapters in this group for regional variations specific to the underwater archaeological record).

At the Last Glacial Maximum (LGM), the ice sheet covered all of Norway, Sweden and Finland, extending eastwards into northern Russia and westwards across the North Sea. Its southern margin covered parts of Denmark, northern Germany and Poland, most of the Baltic States (Lithuania, Latvia and Estonia) and Russian territory abutting the Baltic coastline. The maximum thickness of the ice sheet was $2700 \mathrm{~m}$, centred over NE Sweden and the northernmost shores of the Baltic Basin (The Gulf of Bothnia), thinning out towards the edges. As the ice sheet melted, the mass loading on the Earth's crust changed, previously glaciated areas began to rebound and areas at and beyond the southern and western ice margins subsided. These adjustments happened slowly and continue in many areas to the present day.
The greatest rates of isostatic uplift occurred in the areas where the ice was thickest, especially northern Norway and north-east Sweden, and uplift of shorelines has reached a maximum elevation of $270 \mathrm{~m}$ above present sea level in these regions. Here, uplift consistently outpaced the eustatic rise of sea level, with the result that relative sea level has dropped continuously from the onset of deglaciation to the present day, and the earliest shorelines have been lifted above the present sea level (see Glorstad et al., Chap. 6, Fig. 6.2, this volume). Along parts of the southern and western margins, land has subsided, and the sea has steadily encroached on the land, amplifying the eustatic rise of sea level and submerging shorelines, even those of relatively late date (see Jöns et al., Chap. 5, Fig. 5.3 and 5.4). In intermediate regions, relative sea-level rise shows a more complex pattern of rise and fall, especially on shorelines affected by the periodic damming back of the water in the Baltic Basin and its reconnection with the world oceans, notably in southern Sweden (see Nilsson et al., Chap. 4, Fig. 4.3).

\subsubsection{The Baltic Sea}

The Baltic Sea is one of the largest inland seas in the world and today is a brackish-water basin connected to the Atlantic Ocean via the North Sea through the narrow straits and islands that separate the Jutland Peninsula of Denmark from southern Sweden (from west to east the Little Belt, the Great Belt and the Öresund). It was originally created by the gouging out of deep basins by ice action, a process which has largely erased evidence of surface deposits earlier than the LGM. As the ice sheets melted after the LGM, the Baltic went through four stages between c. 16,000 and 8000 years ago (16 ka and $8 \mathrm{ka} \mathrm{cal} \mathrm{BP}$ ): two periods as an isolated freshwater lake and two periods of connection with the world ocean.

In the first stage, known as the Baltic Ice Lake, from c. $16 \mathrm{ka}$ to $11.7 \mathrm{ka}$ cal BP, meltwaters began to fill the southern Baltic basin but were dammed back by the persistence of an ice barrier at the south-western end and later by isostatic land uplift, 
and this lake remained covered with ice for most of the year (see Bailey et al., Chap. 3, Figs. 3.2b and $3.3 \mathrm{c}$, this volume). During this period, isostatic uplift kept pace with eustatic sea-level rise, maintaining the isolation of the Baltic as a freshwater lake except for a narrow outlet through the Öresund. As the land in the Öresund area uplifted, so the outlet of water in the Öresund cut down through glacial deposits, maintaining the level of the Baltic lake at about the same height as sea level. However, at some point, the downcutting reached the more resistant limestone, which blocked the outlet. Continued uplift and continued melting of the ice sheet resulted in a rise in the Baltic water level above that of the contemporaneous sea level (Nilsson et al., Chap. 4, this volume).

Between c. $13 \mathrm{ka}$ and $10.7 \mathrm{ka}$, there were two short-lived periods of reconnection with the sea through the southern Swedish lowlands (Rosentau et al. 2017, Fig. 8.12), separated by a brief period of renewed damming by ice readvance during the Younger Dryas. The second of these is known as the Yoldia Sea stage, dating between c.11.7 and 10.7 ka cal BP (see Bailey et al., Chap. 3, Fig. $3.3 \mathrm{~d}$, this volume). These episodes of reconnection with the sea resulted in a rapid drop of water level of at least $25 \mathrm{~m}$ as Baltic waters drained into the North Sea, exposing new areas of land in the south-west Baltic (Nilsson et al., Chap. 4, this volume). Renewed blockage of the Baltic outlet resulted in a new and short-lived episode of lake conditions, the Ancylus Lake period (c.10.7$9.8 \mathrm{ka} \mathrm{cal} \mathrm{BP}$ ), and a renewed rise in lake level (Bailey et al., Chap. 3, Fig. 3.3e, this volume), with inundation of coastal lowlands in the southwest of the Baltic basin. Limited exchange of water with the North Sea through a river system in Denmark maintained brackish-water conditions in the Ancylus Lake. Meanwhile, isostatic uplift had lifted coastlines clear of rising water levels in western Sweden, south-east Norway and the eastern Baltic. After $9.8 \mathrm{ka}$ cal BP, the continued eustatic rise of sea level finally saw the inundation of the Danish Straits and the entry of seawater into the south-western Baltic - the Littorina Transgression beginning at c. $8.5 \mathrm{ka} \mathrm{cal}$ BP (Bailey et al., Chap. 3, Fig. 3.3f, this volume). Sea level continued to rise in this period until about $6 \mathrm{kc}$ cal BP, causing further inundation of land in the south-west Baltic, amplified by continued land subsidence.

Alongside these complicated changes in landsea relationships, climate was changing from periglacial tundra traversed by reindeer migrations to mixed oak forests and temperate fauna. The fertility of lake water and sea water, and their capacity to support aquatic and marine resources available for human exploitation, would also have varied substantially, ranging from the largely infertile waters of the Baltic ice-dammed lake to high levels of productivity in the warm, saline waters of the Littorina period in the Danish Straits and the south-west Baltic and on Late Glacial Norwegian coastlines where the incoming Gulf Stream mixed with meltwater runoff from the land.

\subsection{Palaeoshorelines and Coastal Settlement}

Because of the large regional variations in uplift and subsidence, palaeoshorelines occur at many different elevations. Some have been lifted clear of eustatic sea level rise, opening up a window into the very early use of shoreline settlements and potential use of marine resources on dry-land archaeological sites, notably in Norway and Sweden; other palaeoshorelines have been lifted clear, only to be partly submerged again as sealevel rise overtook uplift of the land, which is the case for parts of the Norwegian coast, yet other palaeoshorelines have remained fully submerged since the time of inundation, notably in southern Sweden, Denmark and the Baltic coast of Germany. These regional differences provide 'windows' into the study of coastlines of different periods. The earliest such periods are on uplifted coastlines in Norway and western Sweden (Bohuslän) and are of Late Palaeolithic and Early Mesolithic date (see Bailey et al., Chap. 3, Table 3.1, for terminology and chronology of archaeological periods). The earliest fully submerged shorelines, of Early Mesolithic date, are in southern Sweden (Scania and Blekinge), while the most easily accessible and best-studied 
submerged sites in Denmark are mostly Middle and Late Mesolithic and in Germany mainly Late Mesolithic and Neolithic. Denmark is of particular interest because the tilting of the land by isostatic adjustment has resulted in concentrations of on-land sites of the Late Mesolithic Ertebølle period on slightly uplifted shorelines in the north and sites of similar age on now-submerged shorelines in the south.

The uplifted shorelines are present along parts of the Norwegian coastline; west, central and northern Sweden; and in Estonia. In most cases Stone Age sites are present on these shorelines from the earliest date that they became visible above present sea level (apsl) or became free of ice and available for occupation. In areas of substantial uplift, the sites are now marooned well inland of the present-day coastline, such as the Early Mesolithic sites of the Södertörn Peninsula near Stockholm in Sweden, which are now 40-80 m apsl or the Norwegian site of Stunner near Oslo at c. $165 \mathrm{~m}$ apsl (Jöns 2011). The earliest such sites are on the uplifted shorelines of Bohuslän in western Sweden where large concentrations of sites of the Late Palaeolithic Hensbacka culture dating from c. $12 \mathrm{ka}$ cal BP are associated with very high levels of marine productivity (Schmitt et al. 2006, 2009). Further north in Norway, coastlines became ice-free as early as $13.8 \mathrm{ka}$ cal BP, but coastal sites are not present until $11.2 \mathrm{ka}$ cal BP because access from the south was blocked by an ice barrier until that time (Glorstad et al., Chap. 6, this volume). Once the Norwegian coastline became accessible, colonisation was rapid-almost instantaneous within the margins of error of radiocarbon dating-with an economy based on seal hunting, some hunting of elk and reindeer in the hinterland and settlements with dwellings comprising stone-built foundations at sites such as Nyhamna and Vega (Bjerck 2008).

The presence of archaeological sites on uplifted shorelines has dominated the study of the earlier Stone Age in Norway and Sweden. However, as Glorstad et al. (Chap. 6, this volume) point out, there are significant gaps in this on-land archaeological record that can only be filled by underwater investigations. The acid soils associ- ated with so much of the regional geology mean that sites on the present-day land surface have very few if any organic remains; details of subsistence economy can be reconstructed only by indirect means, mainly from inferences about the functions of stone tools, the location of sites and ecological reconstructions of potential resource availability. Bone remains, let alone wooden artefacts, are rare or absent. Moreover, on the outer coastlines of southern and northern Norway, coastal sites are missing from the Early Mesolithic period because the coastlines of this period are now largely submerged. This is of particular significance in Norway because settlement was always concentrated on or close to the coastline because of the harsh climate and the mountainous nature of the immediate hinterland. Underwater investigations therefore have an important role to play, both in filling otherwise unexplained gaps in coastal site distributions and as sources of evidence for subsistence economy and the organic component of the material culture.

In Norway underwater investigation has been overshadowed by the emphasis on terrestrial archaeology and by the much more abundant data from underwater sites in neighbouring Denmark and Germany. Nevertheless, the number of finds is surprisingly large - 83 formally recorded sites. Most are isolated finds of stone tools, but animal bones have been recovered in some locations. At the Early Mesolithic Hummervikholmen underwater site, human skeletal remains are well preserved. Stable isotope analysis of the bones has revealed a heavy reliance on marine resources, and a DNA analysis has identified a genetic origin in populations from both Western Europe and Eastern Europe. These results hint at the potentially very rich additional information that can be obtained from underwater finds with good organic preservation, and it is clear that there are many stretches of the Norwegian coastline with submerged Stone Age shorelines in relatively shallow and easily accessible water awaiting investigation.

In Sweden, the situation is quite similar in that emphasis has been devoted to sites on land rather than to underwater investigations, apart from pioneer discoveries of underwater Stone Age finds in the Öresund Strait in the 1970s (Nilsson et al., 
Chap. 4, this volume). In the past decade, renewed geological and archaeological investigations have revealed favourable conditions for the preservation of underwater landscapes and archaeological sites, especially in the period between c. 11.5 and $8.5 \mathrm{ka}$ (coinciding with the Early Mesolithic period) when some $3500 \mathrm{~km}^{2}$ of the Baltic seafloor was exposed as dry land before being inundated by the Ancylus and Littorina transgressions. This landscape is now at depths ranging from $\mathrm{c}$. $22 \mathrm{~m}$ to $10 \mathrm{~m}$ bpsl with abundant evidence of submerged forests, river estuaries, lakes, bogs and palaeoshorelines. At least 44 underwater sites have been recorded. and many have been testexcavated, though larger-scale excavations comparable to those conducted in Denmark and Germany have yet to be undertaken.

Notable finds in Sweden are the materials found at the site of Haväng. Wooden artefacts include remains of a stationary fish weir at 9-8.8 ka cal BP, making this the earliest fish weir in the region, earlier than the earliest examples in Denmark or Germany discussed below and the earliest so far known anywhere in the world. Cutmarked animal bones and wooden artefacts are also found in earlier deposits at this site, dating back to at least $10.7 \mathrm{ka}$ cal BP. In situ deposits of a similar age and with similar potential for preservation of organic materials are present on other coastlines in southern Sweden, including remains of human burials. Also, shipworm (Teredo spp.), a wood-boring marine mollusc capable of damaging and ultimately destroying submerged wood, is, so far, absent because of the low salinity of the Baltic seawater in this region.

The Swedish material is of exceptional interest because it is the only region that provides easy access to deposits associated with a submerged Early Mesolithic coastal landscape, sites located on palaeoshorelines adjacent to a productive marine environment, and excellent conditions of preservation. Coastlines of this period are either absent elsewhere, too deeply submerged to be easily accessible, associated with unproductive marine environments, or on uplifted shorelines without organic preservation. As Nilsson et al. (Chap. 4, this volume) point out, the apparent evidence for a transition to greater emphasis on permanent coastal settlement and marine resources from the Middle Mesolithic period onwards in Sweden may be illusory, because it has been based on a comparison between Maglemosean (Early Mesolithic) sites originally located some distance inland from their contemporaneous coastlines and Ertebølle (Middle and Late Mesolithic) sites located on the shoreline.

Similar comments apply to Denmark and Germany. In Denmark the great majority of underwater finds are from the inner straits and archipelagos at the entrance to the Baltic. Very few of these finds are of Early Mesolithic (Maglemosean) date, and those that have been recovered lie at the very end of this period with radiocarbon dates of 9.4-8.3 ka cal BP (Bailey et al., Chap. 3, this volume). This appears to reflect the relatively late establishment of marine conditions in this region associated with the Littorina transgression, dating back at earliest to $9.8 \mathrm{ka} \mathrm{cal} \mathrm{BP}$ and to the fact that shorelines of this period are quite deeply submerged or have been eroded away. Similarly in Germany, submerged coastal sites on the Baltic coastline are associated with the Littorina transgression, and the earliest radiocarbon-dated sites date from c. $8.4 \mathrm{ka}$ onwards (Jöns et al., Chap. 5, this volume). Systematic excavation and recovery of materials from Early Mesolithic sites in Sweden have yet to be undertaken but will undoubtedly help to fill what remains a very large gap in our current understanding of long-term trends in coastal settlement and exploitation of marine resources in Scandinavia and the Baltic.

\subsection{Conditions of Discovery and Preservation}

The best insights into these issues come from Denmark and Germany, where investigations over a long period have resulted in a large archive of information including systematic excavations-four principal excavations in Denmark and eight in Germany - that have produced abundant finds and details of preservation conditions, stratigraphic associations and depositional environments. An important point that emerges from 
these excavations is that the culture layers that have preserved the great majority of organic finds are refuse dumps of materials that were originally deposited in shallow water at the shore edge, whereas the adjacent settlement areas on dry land have been disturbed or largely destroyed by marine inundation and erosion.

In Denmark, the site of Tybrind Vig offers the classic example of preservation conditions on underwater sites. This is a site that was systematically excavated over a 10 -year period and is one of the best-known and best-reported underwater excavations in Europe. The main settlement area extended along the shore for c. $130 \mathrm{~m}$ and extended over an area of $2600 \mathrm{~m}^{2}$, judging by the concentration of stone tools recovered from the original land surface (Bailey et al., Chap. 3, this volume). However, apart from two human burials, which probably survived the destructive action of waves and water currents because they were dug below the original land surface and covered over, other settlement features such as evidence of dwellings and pits, or preservation of organic materials, are absent from this area. All the organic finds of bone, antler and wood, and a number of stone tools, come from a refuse area in front of the site. This refuse area extended over a similar area (c. $2000 \mathrm{~m}^{2}$ ), of which $192 \mathrm{~m}^{2}$ was excavated. The finds recovered in this area mostly represent artefacts discarded there after use in the adjacent settlement area or redeposited from their original position and materials such as logboats, fish traps and fishing equipment abandoned in situ in the shallow-water zone after use.

Similar features are present at the other excavated sites in Denmark, with a land area that has been disturbed or eroded and a refuse area in the adjacent marine zone where most of the organic material has been preserved and recovered. However, not all is destruction on the original land surface, and pockets of well-preserved material are occasionally present, notably stone-lined hearths, one at Ronæs Skov with small branches of wood used for the fire and a tinder fungus and another at Argus Bank with charred food remains (Bailey et al., Chap. 3, this volume).

In addition to implements of stone, bone and antler, this refuse zone at Tybrind Vig yielded a large collection of wooden artefacts including leister prongs, dugout logboats, paddles, handles for hafted axes, shafts for spears and arrows, bows, the remains of a wicker fish trap and fish weirs comprising wooden stakes and softer withies woven together to make a stationary structure. Other organic materials include textiles, cordage and uncharred remains of food plants. These finds revealed a hitherto little-known aspect of Ertebølle material culture, much of it associated with fishing or other maritime activities. This is consistent with the faunal remains at Tybrind Vig, which include bones of cod, seal and porpoise, and with the location of the site as one of a group of sites clustered around the narrow mouth of a shallow bay, ideally situated to trap quantities of fish and other marine animals. Bones of land mammals such as red deer, roe deer and wild boar are also present, and sites of the same period are present on rivers and lake edges up to $10 \mathrm{~km}$ inland, indicating a terrestrial and hinterland component to the coastal economy.

One of the outstanding features of the Danish evidence is the remains of stationary fish weirs. The largest and best preserved of these are from the early Neolithic period. At Oleslyst, a complete panel was recovered, $5.5 \mathrm{~m}$ long and $1.7 \mathrm{~m}$ high, comprised of stout vertical stakes at halfmetre intervals with long, flexible hazel withies woven horizontally through the stakes to make a tightly woven mesh, believed to have been designed to trap large quantities of eels during their seasonal migrations. The evidence at this site indicates that the original fence comprised a number of these panels extending for at least $30 \mathrm{~m}$ out from the shore. At Neksel $\varnothing$, a line of stakes extended out to at least $250 \mathrm{~m}$. Similar remains, though more fragmentary, are present from the Ertebølle period, and the earliest is from a pre-Ertebølle context at Kalø Vig dated at c. $8.4 \mathrm{ka}$ cal BP. As noted above, an earlier example has been dated at 9-8.8 ka cal BP at Haväng in Sweden. Hundreds of vertical stakes, mostly of hazel, would have been needed in the construction of these fences, and thousands of withies. The quantities of hazel rods required for fence construction and their uniform shape are clear evidence of coppicing. 
The working of wood for a wide variety of purposes shows a sophisticated understanding of wood technology, including an appreciation of the properties of different types of wood and their suitability for different purposes-hazel for long uprights, ash for spear shafts, guelder rose for arrow shafts, elm for bows, applewood for axe handles and lime for logboats. The fish weirs are testament both to the communal labour required in their construction and maintenance and to the large quantities of food made available and their important role in sustaining relatively large communities at permanent settlements on the shoreline. The logboats are also an important feature of the technology, the largest known being nearly $10 \mathrm{~m}$ long. These boats would have played an important role in offshore fishing, in transportation and in social communication.

In Germany, similar evidence has been recovered from the excavated sites on the Baltic coastline, which span a date range from the Kongemosen culture (Middle Mesolithic), through the various phases of the Ertebølle to the Early Neolithic (FNB) - c. 8.4-4.2 ka cal BP (Jöns et al., Chap. 4, this volume). At Neustadt in Lübeck Bay, for example, with one of the more extensive areas excavated, at $110 \mathrm{~m}^{2}$, a very large assemblage of artefacts and organic remains was recovered from a marine refuse area, while the on-land area of the settlement had been destroyed by marine erosion. At Timmendorf-Nordmole I in the Wismar Bay, a similar refuse area provided most of the finds, while the on-land area had been eroded except for a pit with a sediment fill containing some organic remains and the timbers of a collapsed structurethe structure itself was considered by the excavators to be too small for a dwelling. Preservation on land here, as at the Danish sites, appears to be the result of features that had protected the deposit in question from the worst ravages of marine erosion, in this case the presence of a sediment-filled pit. A hearth area was also recorded at Breetzer Ort in Rugen, where it had been protected by two fallen tree trunks. Hearth areas sealed beneath peat and marine sediments were also recovered at Jäckelberg-Huk and Timmendorf-Normole II in Wismar Bay. In general, though, preservation of features on the original land is the exception, and the vast majority of finds come from marine refuse areas in front of the sites.

The range of material culture in the German Baltic sites, particularly items made of wood, is very similar to the Danish sites, with remains of fish weirs, logboats, leister prongs, paddles, wicker work and cordage.

In addition, there are two distinctive features worth noting. The first is the way in which the sites of the Wismar Bay track the retreat of the shoreline with progressive inundation by the Littorina Transgression and land submergence, demonstrating just how much land was lost and how people adapted to the changing conditions. The earliest site in the sequence, and the deepest at $8.5 \mathrm{~m} \mathrm{bpsl}$, dated at $8.4-8.0 \mathrm{ka}$ cal $\mathrm{BP}$ is Jäckelberg-Huk. The remains of aquatic food are dominated by freshwater fish such as pike and perch and the migratory eel, which spends part of its life in freshwater, in keeping with an early stage in the Littorina transgression when saltwater had not yet penetrated far into the Baltic. One thousand years later, at the sites of JäckelbergNord and Timmendorf-Nordmole II, marine fish are dominant in the food remains along with continuing exploitation of eel.

The second feature is the presence of underwater Neolithic sites. In Wismar Bay, the youngest site in the sequence and the shallowest at $2 \mathrm{~m}$ bpsl is the Early Neolithic Funnel Beaker settlement of Timmendorf-Tonnenhaken dated at 5.2$4.7 \mathrm{ka}$ cal BP. All the bone remains at this site are of domestic cattle and pig, demonstrating that coastal locations remained important for Neolithic settlement even where marine resources were not apparently exploited. At Neustadt, there is continuity of occupation from the late Ertebølle to the Early Neolithic Funnel Beaker culture. Here too, domestic animals are the main species represented in the faunal remains of the Neolithic deposits, but analysis of residues on the inner surface of the Neolithic potsherds shows the presence of aquatic foods and acorns, and both resources are present on the residues of the Ertebølle potsherds from this site, demonstrating some continuity of economic practices across the Mesolithic-Neolithic boundary alongside the introduction of domestic animals. 


\subsection{Reasons for Site Preservation}

The reasons for the survival of so many submerged sites and the preservation of rich assemblages of organic materials are similar throughout the regions discussed here. They are especially clear in Denmark and Germany and are due to three principal factors. The first is the high productivity of the marine environment and a coastal topography of marine channels and inlets that facilitated the easy capture in large quantities of fish and sea mammals during their seasonal migrations, a factor further enhanced by the construction of fish weirs, and one that resulted in concentrations of settlement along the immediate shoreline.

A second factor is the relatively sheltered marine conditions of coastlines in the southwestern Baltic and the Danish Straits, with limited tidal movement and wind fetch, conditions conducive to the preservation of archaeological material. However, even in this protected environment, archaeological deposits are not invulnerable, as is clearly demonstrated by the erosion and destruction by marine action of most of the on-land sectors of the submerged settlements that have been excavated. Rather, the key factor is the fine sediments associated with these marine conditions and their slow but steady accumulation with progressive rise in relative sea level, producing deposits of soft, fine-grained, clay-like gyttja. Materials discarded into these deposits or engulfed by them quickly sink below the surface and are rapidly protected from subaerial degradation and the disturbing or destructive impact of waves and marine currents. Moreover, burial in these sediments followed by permanent submergence under water provides anaerobic conditions that protect organic material from bacterial attack. It is these depositional conditions, combined with the large quantities of cultural material abandoned in the shallow-water zone next to settlements located on the shoreline, that are the key to understanding the number of underwater sites discovered in Denmark and Germany and the quality of organic preservation. Similar conditions are associated with many of the Swedish sites and are also present in Norway.
As always, when considering issues of underwater preservation, there is a delicate balance between sediment accumulation that is sufficiently rapid to provide protection of land surfaces and archaeological materials, but not so rapid as to bury them deeply beyond the reach of easy observation. This is the major contrast between the Baltic and the North Sea coastlines of Denmark and Germany. In the North Sea, the huge volumes of sediment poured into the basin by the large rivers draining the continental land mass have resulted in thick accumulations of recent sediment. In these circumstances, Stone Age material is likely to be deeply buried, and discovery subject to the vagaries of exposure by storms that periodically remove some of the sediment cover or intrusive industrial activities, a point well illustrated by the sites on the German coastline (Jones et al., Chap. 5, this volume).

The third factor is the resources available for investigation. In Denmark the many reported finds are in large part the product of a long history of public and professional interest in which sports divers have made a significant contribution including a major role as volunteers in the underwater excavation of Tybrind Vig (Andersen 2013, pp. 7-8). Also, protective legislation for seabed archaeology has been in place since 1984, overseen by the national heritage agency, with the protection of underwater Stone Age sites as an explicit theme. The predictive 'fishing site' model developed by Anders Fischer and sponsored by the national heritage agency as a tool for management and protection of the underwater cultural heritage has also contributed to the discovery of many new sites (Fischer 1993, 2007). This model is testament to what can be achieved at relatively limited cost using easily accessible data on seabed bathymetry and geology, simple acousticsurvey methods and diver inspection. However, research funding has been limited, especially for larger-scale work, and most investigation has taken place as rescue work in response to industrial activity or the threat of erosion.

In Germany, in contrast, results have been achieved mainly through research-led funding from regional or central government agencies. The SINCOS project, funded through a major 
grant from the central government funding source (Deutsche Forschungsgemeinschaft) has played a major role in new discoveries. Although not explicitly informed by a predictive model for locating sites in the same way as Fischer's Danish work, this project combined acoustic survey and diver inspection systematically to identify and explore palaeoshorelines and conduct excavations at selected sites, resulting in the discovery of 50 new underwater Stone Age sites, eight excavations, and an unusual level of integration across disciplinary boundaries. It is an outstanding example of what can be achieved through large-scale research-led collaboration between marine geophysicists, geologists, climatologists and archaeologists.

\subsection{Industrial Collaboration}

A significant contribution to the development of research on submerged prehistory and the discovery of new finds throughout this region is the degree of collaboration between government heritage agencies, industrial companies working offshore and archaeological and scientific researchers. All the countries in this group are members of the European Union and subject to EU legislation that requires Environmental Impact Assessments (EIAs) to be conducted by industrial companies before embarking on offshore development (see also Parts II and IV of this volume). The relationship between these different stakeholders has evolved somewhat differently in different countries, but in general, underwater cultural heritage is usually included in the impact assessment and has resulted in important discoveries.

An important early example of collaboration is the Great Belt project of Denmark, which resulted in numerous offshore investigations and discoveries of submerged landscape features and archaeology during the construction of the road bridge and rail tunnel between the islands of Funen and Zealand in Denmark (Pedersen et al. 1997; Bailey et al., Chap. 3, this volume). Other examples are the collaboration with a commercial survey company in the 'Landscapes Lost' project in Sweden, which played a key role in the discovery of the finds at Haväng (Holmlund et al. 2017; Nilsson et al., Chap. 4, this volume), and the coring of the seabed during windfarm construction offshore of Norway, which provided key palaeoenvironmental data about palaeoshoreline development and the potential for human occupation on the eastern edge of Doggerland during the Late Glacial and early Postglacial period (Glørstad et al. 2017, and Chap. 6, this volume).

Other recent projects are the construction of the Fehmarn tunnel between the Danish island of Lolland and northern Germany and the Nord Stream pipeline project. In the Fehrmanbelt project, submerged landscape research and heritage management formed a completely integrated part of the planning and implementation of the construction project from its inception in 2008. As part of the EIA, extensive geological, geophysical, biological and archaeological investigations were carried out including seismic and side-scan survey, coring of sediments and geological, geochemical and palaeobotanical analysis. All the costs of survey and analysis were covered by the construction company. The results demonstrated the existence of a freshwater lake before the Littorina transgression and submerged archaeological remains on the Danish side (Dirk Enters et al. 2015).

The Nord Stream pipeline is a gas supply route from Russia through the Baltic Sea to Western Europe, extending for $1200 \mathrm{~km}$ from Portovaya Bay near Vyborg in north-western Russia and ending in Lubmin near Greifswald in north-eastern Germany. The national archaeological authorities in each of the countries involved, principally Russia, Denmark and Germany, were fully integrated in the planning and construction process. Geophysical survey was conducted in a $2 \times 2 \mathrm{~m}$ grid and a $2 \mathrm{~km}$ wide corridor along the route, with ROV and diver inspection of anomalous features, with the project bearing the full costs of these investigations.

Industrial collaborations of this sort are obviously limited to target areas where offshore projects are to be carried out. However, with sufficient planning and organisation, they can provide technical and analytical resources on a scale that is 
rarely possible in research-led projects and are likely to play an increasingly important role in the future.

\subsection{Conclusion}

In reviewing these chapters, two things stand out. The first is the large number of sites and the quality of preservation compared to other areas of Europe, particularly along the coastlines of the Baltic and the Danish Straits. The second is that, despite this wealth of existing information and perhaps because of it, a range of new challenges and opportunities are coming more clearly into focus. Most of the existing information has come from sites in shallow water, mostly $<5 \mathrm{~m}$, easily accessible to SCUBA divers, and hence from sites of relatively late date (mostly from the Middle Mesolithic after c. $8.5 \mathrm{ka}$ cal BP onwards). Even in this period, relatively few sites have received more than a test excavation. Most records refer to individual finds, and it remains unclear in many cases whether these are genuinely isolated specimens or surface indications of more extensive deposits beneath the seabed and if the latter whether they refer to in situ culture layers or redeposited material. For earlier periods, the submerged palaeoshorelines of southern Sweden clearly offer opportunities for investigations of the Early Mesolithic period (c. 11.7 to $8.4 \mathrm{ka}$ cal BP) at depths within relatively easy reach of divers, and the same appears to be likely for some of the submerged coastlines of Norway.

Looking further afield, the gyttja sediments associated with the best conditions of preservation at the known excavated sites are more widely distributed in the Baltic and in the North Sea, according to evidence from geological cores and more extensive evidence of sediments and submerged forests. This is certainly the case further east in the Baltic (Damusyte et al. 2004; Uścinowicz et al. 2011). Judging from isolated finds of artefacts and preliminary palaeoenvironmental investigations, there is considerable potential for the discovery of new submerged sites in Poland, Lithuania and Latvia extending back at least to the Late Palaeolithic period (Kaube 1985;
Kalniņa and Bērziņš 2010; Miotk-Szpiganowicz et al. 2010; Žulkus and Piličiauskas 2010).

On the North Sea coastlines of Germany and Denmark, finds are far fewer and are either relatively late in date or subject to chance exposure because of the much greater thickness of marine sediments compared to the Baltic. Nevertheless, the Maglemosean artefact dredged up from the Danish sector of the Dogger Bank (Bailey et al., Chap. 3, this volume, Fig. 3.4) and the use of a distinctive red flint in the Late Upper Palaeolithic industries of northern Germany with its source on the offshore island of Heligoland (Jöns et al., Chap. 5, this volume, Fig. 5.7) are clear indications that the extensive lowland landscape of Doggerland was an important zone of human activity at periods of lower sea level. It is here that settlements of significantly earlier date in the Late Palaeolithic period or earlier will have to be sought, and there is no reason why submerged palaeoshorelines with topography and depositional conditions comparable to the Mesolithic sites of the Baltic should not be present further out into the North Sea Basin. The technical challenges and costs of finding such features in deep water and most likely buried beneath marine sediments are, of course, much greater, but these challenges are already being addressed by offshore expeditions using research ships with palaeolandscape reconstructions and archaeological objectives in view (e.g., Gaffney et al. 2017; Hepp et al. 2017) and through palaeoenvironmental examination of the very large archive of existing sediment cores from inshore waters (Jöns et al., Chap. 5, this volume).

\section{References}

Andersen SH (2013) Tybrind Vig. Submerged Mesolithic settlements in Denmark. Jutland Archaeological Society Publications, vol 77. Jutland Archaeological Society, Højbjerg

Bjerck H (2008) Norwegian Mesolithic trends: a review. In: Bailey G, Spikins P (eds) Mesolithic Europe. Cambridge University Press, Cambridge, pp 60-106

Damusyte A, Bitinas A, Kiseliene D, Mapeika J, Petrodius R, Pulkus V (2004) The tree stumps in the south eastern Baltic as indicators of Holocene water level fluctuations. In: IGC-IUGS-UNESCO (ed) 32nd 
International Geological Congress (Abstracts II), 20th-27th August 2004, Florence, p 1167

Enters D, Wolters S, Blume K, Lücke A, Segschneider M, Theuerkauf M (2015) Multiproxy-Analysen zur spät- und postglazialen Entwicklungsgeschichte des Fehmarnbelts. Siedlungs- und Küstenforschung im Nordseegebiet 38:43-58

Fischer A (1993) Stone Age settlements in the Småland Bight: A theory tested by diving. Miljøministeriet, Skov- og Naturstyrelsen, København (In Danish and English)

Fischer A (2007) Coastal fishing in stone age Denmark evidence from below and above the present sea level and from human bones. In: Milner N, Craig OE, Bailey GN (eds) Shell middens in Atlantic Europe. Oxbow, Oxford, pp 54-69

Gaffney V, Allaby R, Bates R, Bates M, Ch'ng E, Fitch S, Garwood P, Momber G, Murgatroyd P, Pallen M, Ramsey E, Smith D, Smith O (2017) Doggerland and the lost Frontiers project (2015-2020). In: Bailey GN, Harff J, Sakellariou D (eds) Under the sea: archaeology and palaeolandscapes of the continental shelf. Springer, Cham, pp 305-319

Glørstad H, Gundersen J, Kvalø F (2017) The northern coasts of Doggerland and the colonisation of Norway at the end of the Ice Age. In: Bailey G, Harff J, Sakellariou D (eds) Under the sea: archaeology and palaeolandscapes of the continental shelf. Springer, Cham, pp 285-303

Hepp DA, Warnke U, Hebbeln D, Mörz T (2017) Tributaries of the Elbe palaeovalley: features of a hidden palaeolandscape in the German Bight, North Sea. In: Bailey GN, Harff J, Sakellariou D (eds) Under the sea: archaeology and palaeolandscapes of the continental shelf. Springer, Cham, pp 211-222

Holmlund J, Nilsson B, Rönnby J (2017) Joint explorations of the sunken past. Examples of maritime archaeological collaboration between industry and academia in the Baltic. In: Bailey GN, Harff J, Sakellariou D (eds) Under the sea: archaeology and palaeolandscapes of the continental shelf. Springer, Cham, pp 53-63

Jöns H (2011) Settlement development in the shadow of coastal changes - case studies from the Baltic rim. In: Jöns H, Björck S, Hoth P (eds) The Baltic Sea basin. Springer, Berlin/Heidelberg, pp 301-336
Jöns H, Harff J (2014) Geoarchaeological research strategies in the Baltic Sea area: environmental changes, shoreline-displacement and settlement strategies. In: Evans AM, Flatman JC, Flemming NC (eds) Prehistoric archaeology on the continental shelf: a global review. Springer, New York, pp 173-192

Jöns H, Björck S, Hoth P (eds) (2011) The Baltic Sea basin. Springer, Berlin/Heidelberg

Kalniņa L, Bērziņš V (2010) Latvia's former coastlines: the state of research on palaeolandscapes and Stone Age archaeology. SPLASHCOS meeting, 10-11 March 2010, York. https://www.splashcos.org/events

Kaube A (1985) Harpun z poroża wyłowiony z Bałtyku. Materiały Zachodniopomorskie 31:409-412

Miotk-Szpiganowicz G, Pomian I, Uścinowicz Sz, Was M, Witkowski A (2010) Underwater research in Poland. SPLASHCOS meeting, 10-11 March 2010, York. https://www.splashcos.org/events

Pedersen L, Fischer A, Aaby B (eds) (1997) The Danish Storebælt since the ice age: man, sea and forest. A/S Storebæltsforbindelsen, Copenhagen

Rosentau A, Bennike O, Uscinowicz S, MiotkSzpiganowcz G (2017) The Baltic Sea basin. In: Flemming NC, Harff J, Moura D, Burgess A, Bailey GN (eds) Submerged landscapes of the European continental shelf: quaternary paleoenvironments. Wiley, Chichester, pp 103-133

Schmitt L, Larsson S, Schrum C, Alekseeva I, Tomczak M, Svedhage K (2006) 'Why they came': the colonization of the coast of western Sweden and its environmental context at the end of the last glaciation. Oxf J Archaeol 25(1):1-28

Schmitt L, Larsson S, Burdukiewicz ZJ, Svedhage K, Zamon J, Steffen H (2009) Chronological insights, cultural change, and resource exploitation on the west coast of Sweden during the late Palaeolithic/early Mesolithic transition. Oxf J Archaeol 28(1):1-27

Uścinowicz S, Miotk-Szpiganowicz G, Krąpiec M et al (2011) Drowned forests in the Gulf of Gdańsk (southern Baltic) as an indicator of the Holocene shoreline changes. In: Harff J, Björck S, Hoth P (eds) The Baltic Sea basin. Springer, Berlin/Heidelberg, pp 219-231

Žulkus V, Piličiauskas G (2010) Stone Age archaeology below sea level in Lithuania: on the shelf and at the coast. SPLASHCOS meeting, 10-11 March 2010, York. https://www.splashcos.org/events

Open Access This chapter is licensed under the terms of the Creative Commons Attribution 4.0 International License (http://creativecommons.org/licenses/by/4.0/), which permits use, sharing, adaptation, distribution and reproduction in any medium or format, as long as you give appropriate credit to the original author(s) and the source, provide a link to the Creative Commons licence and indicate if changes were made.

The images or other third party material in this chapter are included in the chapter's Creative Commons licence, unless indicated otherwise in a credit line to the material. If material is not included in the chapter's Creative Commons licence and your intended use is not permitted by statutory regulation or exceeds the permitted use, you will need to obtain permission directly from the copyright holder.

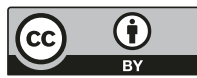

